\title{
Effects of recycled paperboard mill wastes on the properties of non-load-bearing concrete
}

\author{
S. F. Seyyedalipour ${ }^{1} \cdot$ D. Yousefi Kebria ${ }^{1} \cdot$ M. Dehestani ${ }^{1}$
}

Received: 22 December 2014/Revised: 29 July 2015/Accepted: 17 August 2015/Published online: 27 August 2015

(C) Islamic Azad University (IAU) 2015

\begin{abstract}
Population growth and increasing demand for industrial enterprises such as pulp and paper production lead to environmental problems such as over-exploitation of resources and pollution of soil, air and water. Thus, for the importance of reducing the negative effects of incineration and landfilling of wastes for the protection of environment, two kinds of recycled paperboard mill wastes were used as partial replacement of sand (volume percentage), to produce non-load-bearing lightweight concrete. Waste type 1 consists of paperboard chips mixed with small amount of sand, and waste type 2 consists of paperboard chips mixed with expanded polystyrene and nylon. This study was carried out in laboratory scale to achieve acceptable strength and minimum density by using maximum amount of waste, in accordance with ASTMC129 for non-load-bearing lightweight concrete construction. Therefore, three types of concrete, including concrete containing waste type 1 (replacing 0, 60, 70 and $80 \%$ of waste and sand), concrete containing waste type 2 (replacing $0,55,75$ and $95 \%$ of waste and sand) and concrete containing both waste types, were constructed. Different tests on the fresh and hardened concrete, including slump, $\mathrm{pH}$, oven-dry density, compressive and tensile strengths, flexural strength, flexural toughness and water absorption, were carried out. The results indicate that the use of waste type 1 is more reliable than waste type 2 in terms of concrete specifications and standard-conforming viewpoints. Results revealed that use of these wastes in concrete can
\end{abstract}

S. F. Seyyedalipour f.seyyedalipour@gmail.com

1 Faculty of Civil Engineering, Babol Noshirvani University of Technology, Babol, Iran save the paperboard industry disposal costs and produce 'greener concrete' for construction.

Keywords Lightweight concrete $\cdot$ Compressive strength · Oven-dry density · Greener concrete

\section{Introduction}

Recently, most municipal and industrial wastes have been disposed of in landfills. However, the increasing refusal of communities to have landfills nearby, as well as the increased pressure from environmental agencies to require proper waste management, is creating the need for alternative disposal consistent with environmental needs at a rational cost. Four main processes are involved in pulp and paper industry, namely the chemical pulping (Kraft process), mechanical and chemical-mechanical pulping, recycled fiber processing and papermaking-related processes (Demir et al. 2005). The raw materials are received as logs directly from the forest or as by-product chips from some other wood industries such as sawmills and recovered fibers.

The use of waste materials has some benefits: It helps to save the natural resources; it decreases the pollution of the environment, and it also helps to save and recycle energy in production process (Hassani et al. 2005). The use of waste materials represents a way of solving some problems of solid waste management in many communities. In addition, appropriate landfill is becoming more difficult to find (Ngoc and Schnitzer 2009). Wastes could be valuable materials as alternative resources for building and some other applications (Van Beers et al. 2009).

In recent years, different methods have been evaluated to solve the wastes problems (Treloar et al. 2003; 
Hınıslıoğlu and Ağar 2004; Modolo et al. 2010; Sutcu and Akkurt 2010; Raut et al. 2012; Tan et al. 2013; Yeheyis et al. 2013). These researches have laid a well foundation for recycling municipal and industrial wastes. A study from Iran has recycled lignocellulosic waste materials to produce high-value products (Enshaeieh et al. 2015). A paper from Taiwan has used metal sludge mixed with mining residues to be recycled into lightweight aggregate (Huang et al. 2007). A work from Spain has utilized mining and industrial wastes to produce lightweight aggregate (González Corrochano et al. 2011). Sutcu et al. (2014) investigated the thermal behavior of hollow clay bricks made up of paper waste. Fava et al. (2010) evaluated the use of paper mill sludge ash as a supplementary cementitious material in mortars and concrete manufacturing. Producing lightweight fillers from waste glass and paper sludge ash was investigated by Spathi et al. (2015). Raut et al. (2013) in their research study evaluated the feasibility of utilizing recycle paper mill residue and rice husk ash for making construction bricks. Yadollahi et al. (2013) probed the possibility of making papermaking sludge/cement composite products using solid waste of papermaking sludge. The effects of partial replacement of Portland cement by wood fiber waste, rice husk ash and limestone powder waste for producing a lightweight concrete block as a building material were investigated by Torkaman et al. (2014). The effects of size and shape of recycled polyethylene terephthalate (PET) aggregate on the fresh and hardened properties, including abrasion resistance of concrete, were evaluated by Sikia and de Brito (2014).

The pulp and paper industry generates large volume of wastes which depend on the type of technology. These materials possess health hazards and esthetic disposal problems. Paper fibers can be recycled only a limited number of times before they become too short or weak to make highquality paper. It means that the broken, low-quality paper fibers are separated out to become waste sludge.

The produced wastes consist of organic and inorganic materials which can be potentially used. Recent studies confirmed that a variety of residues can be used as raw materials in the construction industry. As a result, reusing wastes is economically and environmentally important (Ahmadi and Al-Khaja 2001; Magalhães et al. 2004; Andrade et al. 2003; Galbenis and Tsimas 2006). Depending upon their chemical composition, these wastes can be incorporated into mortars, brick, ceramic, cement clinker, bituminous mixes, etc., to reduce the cost of product and also to improve environmental protection. The waste incorporation in construction materials also enables the stabilization of toxic substances and heavy metals, reducing its potential toxicity by lowering components mobility (Gemelli et al. 2001). Examples of wastes successfully tested as an alternative are municipal solid waste incineration fly ash, steel slag, phosphate-coating sludge and several compounds, namely $\mathrm{ZnO}, \mathrm{PbO}$ and $\mathrm{CdO}$ (Caponero and Tenório 2000; Barros et al. 2004; Saikia et al. 2007; Tsakiridis et al. 2008).

As early as the 1940 s, companies, researchers, entrepreneurs and knowledgeable individuals were looking for to identify alternatives for the management of paper industry solid wastes. These efforts have resulted in a significant volume of research and actual experience related to the efficacy of a wide variety of solid waste management techniques. Some of these techniques have been proven to be viable and environmentally safe waste management. Most of the researches for solid waste management have focused on the conventional alternatives such as landfilling, burning or incineration, and land application. The viability of alternative management strategies depends on four factors: technical feasibility, cost, available markets and potential ability. The relative significance of these factors varies according to business strategy location and waste characteristics of the mills. Due to the large volumes of waste generated, the high moisture content of the waste and the changing waste composition as a result of process conditions, recovery methods are usually expensive and their environmental impact is still uncertain (Monte et al. 2009). As a result, it is substantial to continue research for different applications of wastes, however, considering the environmental and economical aspects of these treatments is inevitable.

The purpose of this study is to assess the performance of concretes produced with recycled paperboard mill wastes. The concrete properties were considered to satisfy requirements for non-load-bearing lightweight concrete according to ASTM C129 (The average oven-dry density of 3 units for lightweight concrete should be less than $1680 \mathrm{~kg} / \mathrm{m}^{3}$. The minimum compressive strength, average of 3 units and individual unit for lightweight concrete should be 4.14 and $3.45 \mathrm{MPa}$, respectively.). Most of the studies concerning the incorporation of residues into construction materials are based on the tests at laboratory or pilot scale (Barros et al. 2004; Saikia et al. 2007; Trezza and Scian 2007; Tsakiridis et al. 2008). This full-scale experimental work was carried out on the years of 2013 and 2014 at the concrete and environment laboratories of Babol University of Technology.

\section{Materials and methods}

\section{Cement}

The Portland cement of type 2 was used in this study. The chemical and physical properties of cement are presented in Table 1. 
Table 1 Chemical compositions and physical properties of cement

\begin{tabular}{ll}
\hline Chemical compositions (weight percent) & \\
$\mathrm{SiO}_{2}$ & 21.90 \\
$\mathrm{Al}_{2} \mathrm{O}_{3}$ & 4.86 \\
$\mathrm{Fe}_{2} \mathrm{O}_{3}$ & 3.30 \\
$\mathrm{CaO}$ & 63.33 \\
$\mathrm{MgO}$ & 1.15 \\
$\mathrm{SO}_{3}$ & 2.10 \\
$\mathrm{CaCO}_{3}$ & - \\
$\mathrm{L.O.I}$ & 2.40 \\
Physical properties & \\
$\mathrm{Blaine}\left(\mathrm{cm}{ }^{2} / \mathrm{g}\right)$ & 3050 \\
Expansion (autoclaved) (\%) & 0.05 \\
Compressive strength (MPa) & 3 days: 18.5 \\
& 7 days: 29.5 \\
& 28 days: 39.7 \\
\hline
\end{tabular}

\section{Aggregate}

Crushed gravel with maximum size of $12.5 \mathrm{~mm}$ in accordance with ASTM-C33-92, standard of grading curve and the river-type sand (passed through Sieve No. $4.75 \mathrm{~mm}$ ) with the value of $\mathrm{SE}=76 \%$ were used for this study.

\section{Wastes}

Two types of recycled paperboard mill wastes provided by Pouya Ayesh Mazand Company in Babol Industrial Park, Iran, were used in this study. Waste type 1 consists of paperboard chips mixed with small amount of sand, and waste type 2 consists of paperboard chips mixed with expanded polystyrene (EPS) and nylon. These wastes are shown in Fig. 1. Physical, chemical, microbial and bacterial characteristics of wastes are given in Table 2.

\section{Concrete mixture design}

Waste materials used in this study have high water-absorption capability which depends on various parameters such as pressure, moisture content and temperature. The variation of water absorption ratio of the waste materials against influencing parameters is significant. Therefore, concrete mixture design was very complicated. After using 33 mixtures design to make concrete, finally 11 mixtures were selected. These mixtures were as follows: series A with waste type $1, \mathrm{~B}$ with waste type 2 and $\mathrm{C}$ with both types of waste types. Table 3 shows the concrete mixture proportions.

\section{Curing the specimens}

Fresh concrete was cast in molds and kept in the laboratory for $24 \mathrm{~h}$. Then, the specimens were removed from the molds and kept in $22-25{ }^{\circ} \mathrm{C}$ water until the proper time for each experiment. Each mixing design included 24 specimens: 15 cubic specimens $(100 \times 100 \times 100 \mathrm{~mm})$, six cylindrical specimens $(300 \times 150 \mathrm{~mm})$ and three beam specimens $(500 \times 100 \times 100 \mathrm{~mm})$. Totally, 264 specimens were prepared for this study.

\section{Results and discussion}

\section{Fresh concrete tests}

\section{Slump}

The concrete slump test is an empirical test that measures the workability of fresh concrete according to ASTMC143. The test is widely used due to the simplicity of apparatus used and simple procedure. The results of concrete slump test are shown in Table 3. The slump values of concrete mixtures containing waste materials were lower than those of conventional concrete mixtures (Mixture

Fig. 1 Appearance of wastes

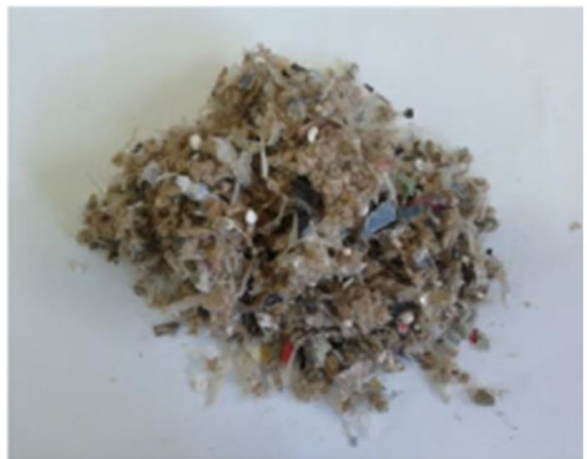

type 2

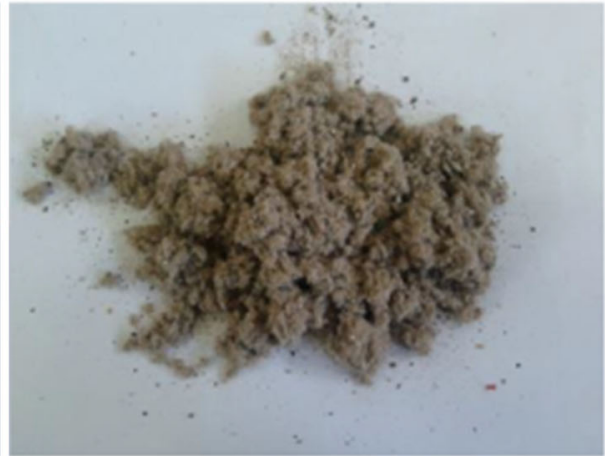

type 1 
Table 2 Physical, chemical, microbial and bacterial characteristics of wastes

\begin{tabular}{|c|c|c|}
\hline Waste type & Type 1 & Type 2 \\
\hline \multicolumn{3}{|l|}{ Physical characteristics } \\
\hline $\mathrm{pH}$ & 7.14 & 7.50 \\
\hline Density $\left(\mathrm{kg} / \mathrm{cm}^{2}\right)$ & 0.74 & 0.33 \\
\hline Moisture content $(\%)$ & 75 & 80 \\
\hline \multicolumn{3}{|c|}{ Analysis of the chemical composition } \\
\hline \multicolumn{3}{|c|}{ Element (weight percent) } \\
\hline $\mathrm{C}$ & 74.42 & 28.82 \\
\hline $\mathrm{Al}$ & 1.34 & 12.43 \\
\hline $\mathrm{Ca}$ & 1.01 & 1.57 \\
\hline $\mathrm{N}$ & 4.07 & 7.07 \\
\hline $\mathrm{Si}$ & 1.41 & 1.63 \\
\hline $\mathrm{Fe}$ & 1.27 & 0.09 \\
\hline $\mathrm{O}$ & 11.37 & 46.49 \\
\hline $\mathrm{P}$ & 0.62 & 0.30 \\
\hline $\mathrm{Ni}$ & 0.11 & 0.01 \\
\hline $\mathrm{Na}$ & 1.25 & 0.41 \\
\hline$S$ & 0.51 & 0.39 \\
\hline $\mathrm{Cu}$ & 0.37 & 0.01 \\
\hline $\mathrm{Mg}$ & 1.43 & 0.31 \\
\hline $\mathrm{Cl}$ & 0.47 & 0.15 \\
\hline $\mathrm{Zn}$ & 0.35 & 0.33 \\
\hline \multicolumn{3}{|c|}{ Microbial and bacterial characteristics } \\
\hline Coli (1/gr) & 0 & 3 \\
\hline F. Coli & Negative & Negative \\
\hline E. Coli & Negative & Negative \\
\hline Salmonella & Negative & Negative \\
\hline Bacterium (1/gr) & $4 \times 10^{7}$ & $5 \times 10^{8}$ \\
\hline
\end{tabular}

Number 1 and Mixture Number 5). Since waste materials have large effective surfaces, they absorb too much water and increase the porosity and decrease the workability of fresh concrete. According to Table 3, workability of the concrete mixtures series A and $\mathrm{B}$ is in medium range.

The wastes have a high water-absorption property. Consequently, when a higher amount of waste was included in the mixture, it requires more water to achieve a given slump. Several factors lead to adverse effects on the workability of concrete: The amount of waste as an aggregate replacement, waste physical properties and the carbon content of the waste are the main reasons for the reduction in concrete workability.

\section{$p H$}

The $\mathrm{pH}$ test was performed to ensure that there is no microbial content in prepared concrete specimen. The results of concrete $\mathrm{pH}$ test are presented in Table 3 .
According to the results of the $\mathrm{pH}$ test $(>12)$, it is obvious that there is no microbial content in prepared concrete mixtures. The $\mathrm{pH}$ value of conventional concrete usually ranges from 12 to 13.5 for new concrete structures (highly alkaline). This is due to the presence of $\mathrm{KOH}$ and $\mathrm{NaOH}$ in the pore solution. Typically, the $\mathrm{pH}$ value decreases as concrete ages.

\section{Hardened concrete tests}

Tests on hardened concrete specimens which include compressive strength, tensile strength, flexural strength, toughness, water absorption and oven-dry density have been done. The results are shown in Table 4 .

\section{Compressive strength}

Compressive strength test was carried out according to British Standards, B.S1881. In this assessment, curing, experimental and the specimen production condition were the same as conventional concrete.

Figure 2 presents the compressive strengths of all 11 mixtures at 7, 14 and 28 days, respectively. It is obvious from Fig. 2a, b that compressive strength decreases with increase in waste content in the mixtures. As the content of the waste increased, the water-cement ratio for the mixture was also increased, since the waste has a high degree of water absorption. The mechanical properties of concrete mixtures contain waste materials, which were highly dependent on the amount of waste content.

According to ASTM-C129 and the results of the experiments, the optimum content of waste type 1 in the sample was $70 \%$, and the optimum content of waste type 2 in the specimen was $75 \%$. The compressive strength of mixtures 9-11 (Fig. 2c) increases with more content of waste type 1 and less content of waste type 2, so it shows that the negative effect of waste type 2 (because of the ingredient of it) on compressive strength of specimens was more than that of waste type 1 . The optimum replacing amount of both waste types with the sand in the specimen was $49 \%$ for waste type 1 and $21 \%$ for waste type 2 .

The overall reduction in compressive strength value of non-load-bearing concrete with replacing high percentage of waste with the sand content can be justified by the wastes centralization tendency, characterized by non-uniform distribution of wastes within concrete matrix. To prevent that happening, the compounds should be mixed well to have better distribution in all parts of the concrete. The other important reason for the reduction in compressive strength is related to the nature of wastes. These wastes initially absorb much water and then, when they compressed in the concrete mixture, they release a part of 
Table 3 Concrete specimens mixture designs

\begin{tabular}{|c|c|c|c|c|c|c|c|c|c|c|c|}
\hline $\begin{array}{l}\text { Mixture } \\
\text { number }\end{array}$ & Series & $\mathrm{w} / \mathrm{c}$ & $\begin{array}{l}\text { Replacement of sand } \\
\text { with waste } \\
\text { (\% by volume) }\end{array}$ & $\begin{array}{l}\text { Cement } \\
\left(\mathrm{kg} / \mathrm{m}^{3}\right)\end{array}$ & $\begin{array}{l}\text { Gravel } \\
\left(\mathrm{kg} / \mathrm{m}^{3}\right)\end{array}$ & $\begin{array}{l}\text { Sand } \\
\left(\mathrm{kg} / \mathrm{m}^{3}\right)\end{array}$ & $\begin{array}{l}\text { Waste } \\
\text { type } 1 \\
\left(\mathrm{~kg} / \mathrm{m}^{3}\right)\end{array}$ & $\begin{array}{l}\text { Waste } \\
\text { type } 2 \\
\left(\mathrm{~kg} / \mathrm{m}^{3}\right)\end{array}$ & $\begin{array}{l}\text { Water } \\
\left(\mathrm{kg} / \mathrm{m}^{3}\right)\end{array}$ & $\begin{array}{l}\mathrm{PH} \\
\text { (value for fresh } \\
\text { concrete) }\end{array}$ & $\begin{array}{l}\text { Slump } \\
(\mathrm{mm})\end{array}$ \\
\hline 1 & A & 0.45 & 0 & 495 & 493 & 1150 & 0 & - & 223 & 12.41 & 105 \\
\hline 2 & & & 60 & 495 & 493 & 454 & 178 & - & 223 & 12.15 & 75 \\
\hline 3 & & & 70 & 495 & 493 & 331 & 206 & - & 223 & 12.18 & 71 \\
\hline 4 & & & 80 & 495 & 493 & 236 & 238 & - & 223 & 12.22 & 66 \\
\hline 5 & B & 0.48 & 0 & 600 & 543 & 845 & - & 0 & 288 & 12.49 & 100 \\
\hline 6 & & & 55 & 600 & 543 & 381 & - & 58 & 288 & 12.24 & 72 \\
\hline 7 & & & 75 & 600 & 543 & 210 & - & 89 & 288 & 12.32 & 61 \\
\hline 8 & & & 95 & 600 & 543 & 30 & - & 102 & 288 & 12.35 & 58 \\
\hline 9 & $\mathrm{C}$ & 0.45 & $42-28$ & 495 & 493 & 331 & 127 & 36 & 223 & 12.32 & 63 \\
\hline 10 & & & 49-21 & 495 & 493 & 331 & 143 & 28 & 223 & 12.30 & 65 \\
\hline 11 & & & $56-14$ & 495 & 493 & 331 & 163 & 19 & 223 & 12.26 & 68 \\
\hline
\end{tabular}

Table 4 Physical properties of the hardened concrete at the age of 28 days

\begin{tabular}{|c|c|c|c|c|c|c|}
\hline $\begin{array}{l}\text { Mixture } \\
\text { number }\end{array}$ & $\begin{array}{l}\text { Compressive } \\
\text { strength (MPa) }\end{array}$ & $\begin{array}{l}\text { Splitting tensile } \\
\text { strength (MPa) }\end{array}$ & $\begin{array}{l}\text { Flexural tensile } \\
\text { strength (MPa) }\end{array}$ & $\begin{array}{l}\text { Toughness } \\
(\mathrm{N} \mathrm{mm})\end{array}$ & $\begin{array}{l}\text { Water } \\
\text { absorption }(\%)\end{array}$ & $\begin{array}{l}\text { Oven-dry density } \\
\left(\mathrm{kg} / \mathrm{m}^{3}\right)\end{array}$ \\
\hline 1 & 45.10 & 3.70 & 6.70 & 4173 & 4.70 & 2205 \\
\hline 2 & 7.30 & 0.95 & 2.05 & 3073 & 16.30 & 1560 \\
\hline 3 & 6.90 & 0.90 & 1.91 & 2301 & 19.40 & 1470 \\
\hline 4 & 3.85 & 0.70 & 1.57 & 2132 & 21.25 & 1330 \\
\hline 5 & 49.05 & 3.95 & 6.82 & 5400 & 4.25 & 2180 \\
\hline 6 & 8.95 & 1.15 & 2.62 & 2616 & 14.25 & 1580 \\
\hline 7 & 7.10 & 0.95 & 2.02 & 3676 & 18.05 & 1475 \\
\hline 8 & 4.90 & 0.80 & 1.58 & 3263 & 24.20 & 1345 \\
\hline 9 & 5.00 & 0.70 & 1.65 & 1968 & 20.90 & 1415 \\
\hline 10 & 5.40 & 0.75 & 1.74 & 1989 & 20.40 & 1430 \\
\hline 11 & 6.05 & 0.85 & 1.80 & 2058 & 20.05 & 1450 \\
\hline
\end{tabular}

absorbed water to the mixture and increase the water-cement ratio.

\section{Tensile strength}

Splitting tensile strength test was conducted according to ASTM-C496. As it can be seen from Table 4 for series A and $\mathrm{B}$, the splitting strength decreased when the waste content in the mixtures increased. Generally increasing waste content is associated with decreasing density and increasing porosity of mixture; thus, lower levels of contact between the waste and the cement paste are created. The splitting strength of mixtures 9-11 increases with higher content of waste type 1 and lower content of waste type 2 , so it shows that the negative effect of waste type 2 on splitting strength of the specimen was more pronounced than that of waste type 1 .

\section{Flexural strength and toughness}

Flexural tensile strength test was performed according to ASTM-C78-94 with a hydraulic universal testing machine (UTM) equipped with strain speed control mechanism (Strain rate of $0.1 \mathrm{~mm} / \mathrm{min}$ ). The specimens were $500 \times 100$ $\times 100 \mathrm{~mm}$ prismatic beams. The distance between the two supports was $400 \mathrm{~mm}$. The results are given in Table 4. The crack initiation at the failure stage is shown in Fig. 3.

It can be concluded that there is a direct relationship between the flexural tensile strength and content of wastes. Same as compression and splitting tensile strength, it is clear for series A and B that flexural strength decreases when the waste content is increased in the mixtures. The flexural strength pertaining to mixtures 9-11 increases for higher content of waste type 1 and less content of waste type 2, so it shows that waste type 2 has a greater negative impact on the 


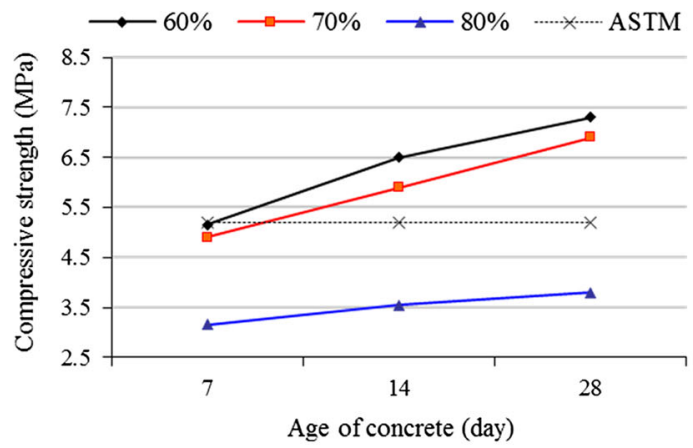

(a)

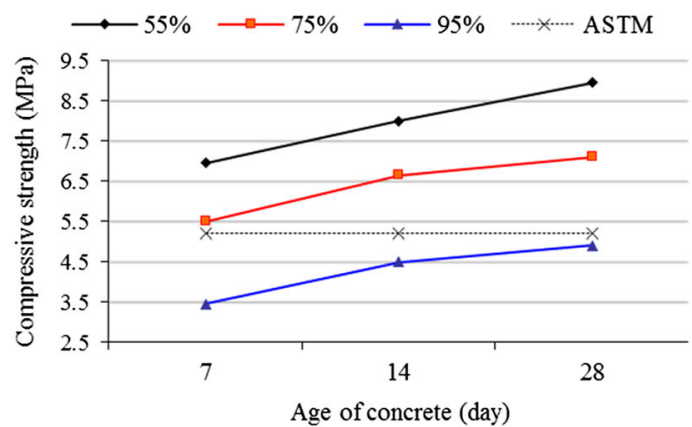

(b)

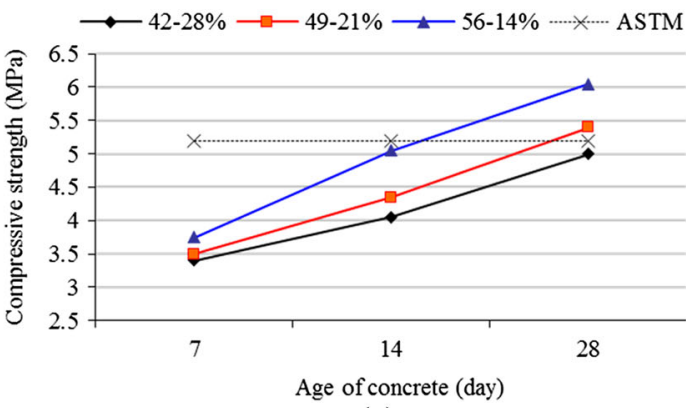

(c)

Fig. 2 Compressive strength of the specimens containing: a waste type 1 , $\mathbf{b}$ waste type 2 and $\mathbf{c}$ both waste types flexural strength compared with waste type 1. Flexural strength results demonstrated that waste materials increase porosity of mixtures which decreases the adhesion between the cement matrix and aggregate interfaces.

The main important effect of adding RPBM wastes to concrete was making links between cracks. The wastes can limit the spread of cracks and give the concrete efficient tolerance against greater stresses after the appearance of cracks. This also improves the plasticity of concrete after the appearance of cracks. This formability is called toughness. Toughness is the ability of a material to absorb energy and plastically deform without fracturing; on the other word it is the amount of energy per unit volume that a material can absorb before rupturing. Area under the (force-extension) curve until the final deformation is considered as the toughness of the concrete. Figure 4 shows the toughness of concrete specimens. From Table 4 and Fig. 4a, for specimens containing waste materials of type 1 , toughness values are generally decreased when the waste content in the mixtures is increased. However, as shown in Fig. 4b, for specimens containing waste type 2 , the toughness increased when the waste content was increased up to $75 \%$ in the mixtures and after that in $95 \%$ decreased again, but still was more than that of $55 \%$ replacement. The toughness values of mixtures 9-11 containing both waste types are increased for higher content of waste type 1 and lower content of waste type 2 . Therefore, it can be concluded that the formability effect of waste type 1 on toughness of specimens was more than that of waste type 2 . Obviously, waste type 1 plays more crucial role in boosting toughness. Also, in spite of conventional concrete specimens, the specimens containing waste materials demonstrated a gradual failure.

\section{Dry density and water absorption}

Water absorption and density tests were carried out according to ASTM-C642-98 at the age of 28 days for all mixture designs. The results are given in Table 4 .
Fig. 3 Splitting point of concrete
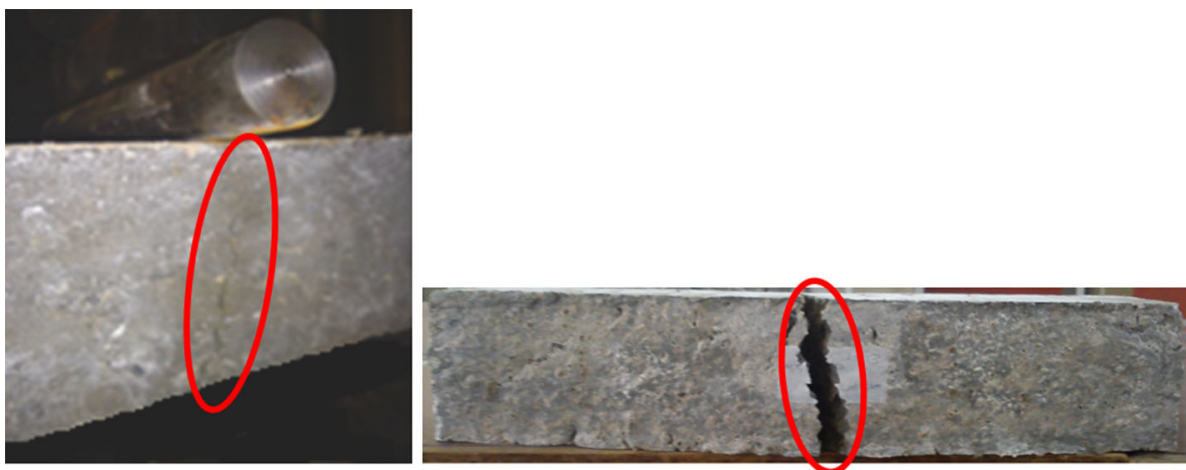


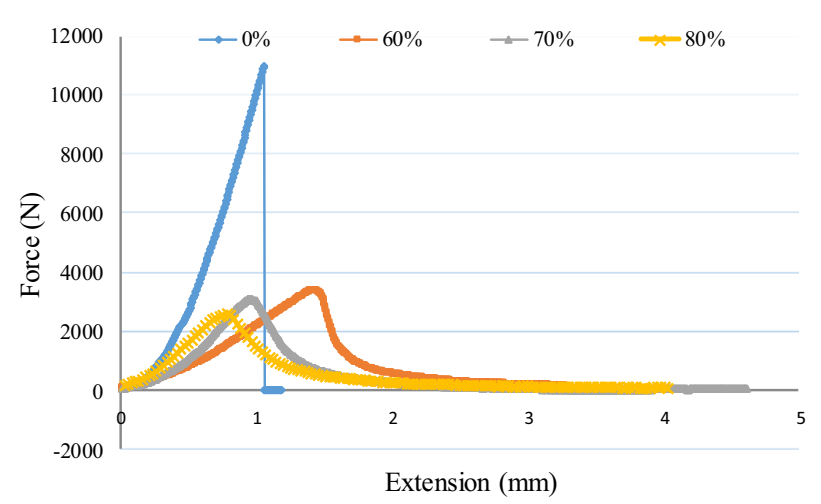

(a)

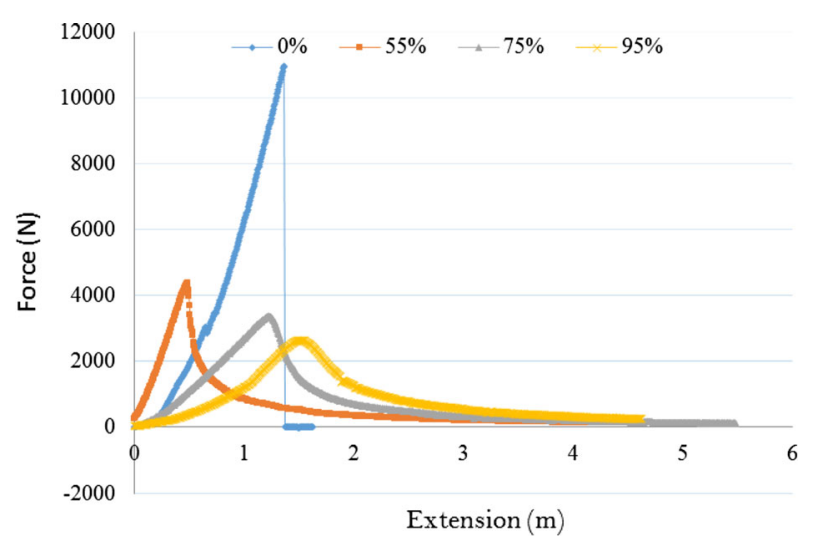

(b)

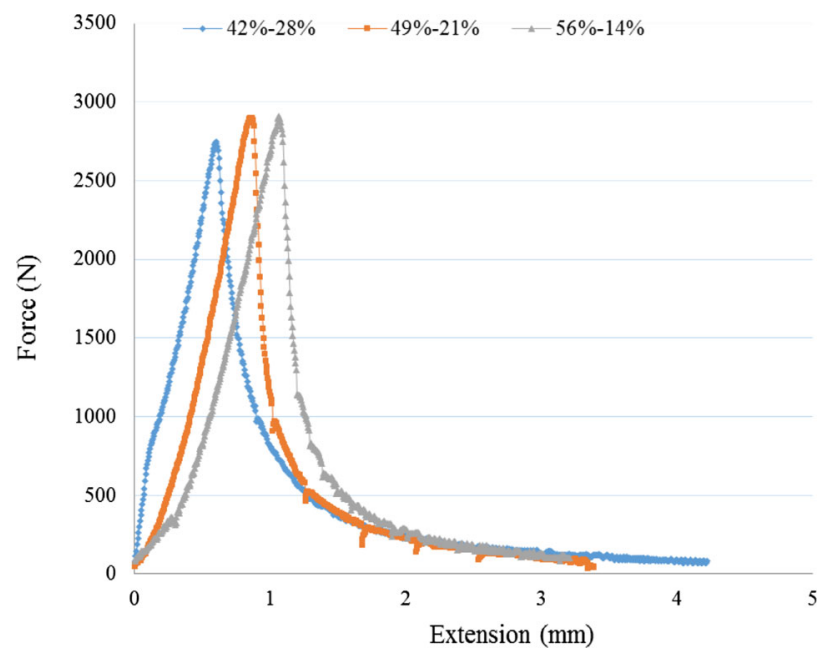

(c)

Fig. 4 Force-extension curves for specimens containing: a waste type $1, \mathbf{b}$ waste type 2 and $\mathbf{c}$ both waste types

Water-absorption capacity of the concrete specimens shows that the addition of wastes significantly increased the water absorption ratio in comparison with the conventional concrete specimen. The water absorption of mixtures 9-11 lightly decreases with more content of waste type 1 and less content of waste type 2, so it shows that the effect of waste type 2 on water absorption of specimens is a little more pronounced. Cellulose fiber which dominates wastes matrix is believed to play a major role in the high absorption.

In a similar manner to strength, density was also noticed to decrease with increasing waste content. The dry density of mixtures 9-11 increased with increase in waste type 1 and decrease in waste type 2 contents, because waste type 2 is more lighter than waste type 1 (according to Table 2). Wastes in their semidry or dry state are quite lighter than sand, and this is considered as the key factor responsible for the significant decrease in the density. According to ASTM C129, all specimens can be classified as light weight.

\section{Conclusion}

The main conclusions of this experimental study can be summarized as follows:

Findings of the fresh concrete assessments show the adverse effects of wastes on the slump test. When a higher amount of the waste was included in the mixture, it required more water to achieve a given slump. According to the results of the $\mathrm{pH}$ test $(>12)$, it is obvious that there is no microbial content in the prepared concrete specimens. Generally, within each group of concrete mixtures A and B (containing wastes from recycled paperboard mill), density, compressive, flexural and splitting strength of concrete decreased with increase in the amount of the waste contents in concrete. Concrete specimens containing both waste types demonstrated that waste type 1 has better performance on energy absorption. The specimens containing wastes have more ductile failures than conventional concrete specimens. Wastes in semidry or dry state are quite lighter than sand, and this is considered as the key factor responsible for the significant decrease in density. In fact, this characteristic could be of advantage especially in masonry partition works for high-rise buildings, where substantial costs can be saved through weight reduction. According to ASTM-C129, in terms of compressive strength and density classification requirements, for specimens containing wastes type $1,70 \%$ of replacement, for specimens containing wastes type $2,75 \%$ of replacement and for specimens containing both waste types, replacing $49 \%$ of sand with waste type 1 and $21 \%$ of sand with waste type 2 would yield the optimum results. It was possible to verify that wastes could be replaced by part of sand for non-load-bearing concrete. Indeed, concrete mixes are acceptable and ready to be tested in industrial scale. In terms of waste management, it is possible to conclude that these wastes which are generated in huge amounts in paper and paperboard production industry can be easily used in non-load-bearing concrete. Use of such wastes in concrete 
can minimize the paper industries disposal costs and produce a 'greener' concrete for construction.

Acknowledgments The authors would like to acknowledge the staffs of the concrete and environment laboratories of Babol University of Technology. Also Nima Ranjbar is acknowledged for his technical assistance.

\section{References}

Ahmadi B, Al-Khaja W (2001) Utilization of paper waste sludge in the building construction industry. Resour Conserv Recycl 32(2):105-113. doi:10.1016/S0921-3449(01)00051-9

Andrade F, Maringolo V, Kihara Y (2003) Incorporation of V, Zn and $\mathrm{Pb}$ into the crystalline phases of Portland clinker. Cement Concr Res 33(1):63-71. doi:10.1016/S0008-8846(02)00928-6

Barros A, Tenório J, Espinosa D (2004) Evaluation of the incorporation ratio of $\mathrm{ZnO}, \mathrm{PbO}$ and $\mathrm{CdO}$ into cement clinker. J Hazard Mater 112(1):71-78. doi:10.1016/j.jhazmat.2004.04.005

Caponero J, Tenório JA (2000) Laboratory testing of the use of phosphate-coating sludge in cement clinker. Resour Conserv Recycl 29(3):169-179. doi:10.1016/S0921-3449(99)00040-3

Demir I, Baspinar MS, Orhan M (2005) Utilization of kraft pulp production residues in clay brick production. Build Environ 40(11):1533-1537. doi:10.1016/j.buildenv.2004.11.021

Enshaeieh M, Abdoli A, Madani M, Bayat M (2015) Recycling of lignocellulosic waste materials to produce high-value products: single cell oil and xylitol. Int $\mathrm{J}$ Environ Sci Technol 12(3):837-846. doi:10.1007/s13762-014-0687-8

Fava G, Ruello ML, Corinaldesi V (2010) Paper mill sludge ash as supplementary cementitious material. J Mater Civ Eng 23(6):772-776. doi:10.1061/(ASCE)MT.1943-5533.0000218

Galbenis CT, Tsimas S (2006) Use of construction and demolition wastes as raw materials in cement clinker production. China Particuology 4(02):83-85. doi:10.1016/S1672-2515(07)60241-3

Gemelli E, Camargo NHA, Brescansin J (2001) Evaluation of paper industry wastes in construction material applications. Mater Res 4(4):297-304. doi:10.1590/S1516-14392001000400013

González Corrochano B, AlonsoAzcárate J, Rodas M, Barrenechea J, Luque F (2011) Microstructure and mineralogy of lightweight aggregates manufactured from mining and industrial wastes. Constr Build Mater 25(8):3591-3602. doi:10.1016/j. conbuildmat.2011.03.053

Hassani A, Ganjidoust H, Maghanaki AA (2005) Use of plastic waste (polyethylene terephthalate) in asphalt concrete mixture as aggregate replacement. Waste Manag Res 23(4):322-327. doi:10.1177/0734242X05056739

Hınıslığlu S, Ağar E (2004) Use of waste high density polyethylene as bitumen modifier in asphalt concrete mix. Mater Lett 58(3):267-271. doi:10.1016/S0167-577X(03)00458-0

Huang SC, Chang FC, Lo SL, Lee MY, Wang CF, Lin JD (2007) Production of lightweight aggregates from mining residues, heavy metal sludge, and incinerator fly ash. J Hazard Mater 144(1):52-58. doi:10.1016/j.jhazmat.2006.09.094

Magalhães JM, Silva JED, Castro F, Labrincha J (2004) Effect of experimental variables on the inertization of galvanic sludges in clay-based ceramics. J Hazard Mater 106(2):139-147. doi:10. 1016/j.jhazmat.2003.11.001

Modolo R, Benta A, Ferreira V, Machado L (2010) Pulp and paper plant wastes valorisation in bituminous mixes. Waste Manag 30(4):685-694. doi:10.1016/j.wasman.2009.11.005
Monte MC, Fuente E, Blanco A, Negro C (2009) Waste management from pulp and paper production in the European Union. Waste Manag 29(1):293-308. doi:10.1016/j.wasman.2008.02.002

Ngoc UN, Schnitzer H (2009) Sustainable solutions for solid waste management in Southeast Asian countries. Waste Manag 29(6):1982-1995. doi:10.1016/j.wasman.2008.08.031

Raut S, Sedmake R, Dhunde S, Ralegaonkar R, Mandavgane SA (2012) Reuse of recycle paper mill waste in energy absorbing light weight bricks. Constr Build Mater 27(1):247-251. doi:10. 1016/j.conbuildmat.2011.07.053

Raut S, Ralegaonkar R, Mandavgane S (2013) Utilization of recycle paper mill residue and rice husk ash in production of light weight bricks. Arch Civ Mech Eng 13(2):269-275. doi:10.1016/j.acme. 2012.12.006

Saikia N, Kato S, Kojima T (2007) Production of cement clinkers from municipal solid waste incineration (MSWI) fly ash. Waste Manag 27(9):1178-1189. doi:10.1016/j.wasman.2006.06.004

Sikia N, de Brito J (2014) Mechanical properties and abrasion behaviour of concrete containing shredded PET bottle waste as a partial substitution of natural aggregate. Constr Build Mater 52:236-244. doi:10.1016/j.conbuildmat.2013.11.049

Spathi C, Vandeperre L, Cheeseman C (2015) Production of lightweight fillers from waste glass and paper sludge ash. Waste Biomass Valoriz. doi:10.1007/s12649-015-9370-7

Sutcu M, Akkurt S (2010) Utilization of recycled paper processing residues and clay of different sources for the production of porous anorthite ceramics. J Eur Ceram Soc 30(8):1785-1793. doi:10.1016/j.jeurceramsoc.2010.01.038

Sutcu M, del Coz Díaz JJ, Rabanal FPA, Gencel O, Akkurt S (2014) Thermal performance optimization of hollow clay bricks made up of paper waste. Energy Build 75:96-108. doi:10.1016/j. enbuild.2014.02.006

Tan W, Wang L, Huang C, Green J (2013) Municipal solid waste incineration fly ash sintered lightweight aggregates and kinetics model establishment. Int J Environ Sci Technol 10(3):465-472. doi:10.1007/s13762-012-0111-1

Torkaman J, Ashori A, Momtazi SA (2014) Using wood fiber waste, rice husk ash, and limestone powder waste as cement replacement materials for lightweight concrete blocks. Constr Build Mater 50:432-436. doi:10.1016/j.conbuildmat.2013.09.044

Treloar GJ, Gupta H, Love PE, Nguyen B (2003) An analysis of factors influencing waste minimisation and use of recycled materials for the construction of residential buildings. Manag Environ Qual Int J 14(1):134-145. doi:10.1108/14777830310460432

Trezza M, Scian A (2007) Waste with chrome in the Portland cement clinker production. J Hazard Mater 147(1):188-196. doi:10. 1016/j.jhazmat.2006.12.082

Tsakiridis P, Papadimitriou G, Tsivilis S, Koroneos C (2008) Utilization of steel slag for Portland cement clinker production. J Hazard Mater 152(2):805-811. doi:10.1016/j.jhazmat.2007.07. 093

Van Beers D, Bossilkov A, Lund C (2009) Development of large scale reuses of inorganic by-products in Australia: the case study of Kwinana, Western Australia. Res Conserv Recycl 53(7):365-378. doi:10.1016/j.resconrec.2009.02.006

Yadollahi R, Hamzeh Y, Ashori A, Pourmousa A, Jafari M, Rashedi K (2013) Reuse of waste sludge from papermaking process in cement composites. Polym Eng Sci 53(1):183-188. doi:10.1002/ pen. 23283

Yeheyis M, Hewage K, Alam MS, Eskicioglu S, Sadiq R (2013) An overview of construction and demolition waste management in Canada: a lifecycle analysis approach to sustainability. Clean Technol Environ Policy 15(1):81-91. doi:10.1007/s10098-012-0481-6 